\title{
Waktu Produksi Yolk Immunoglobulin (IGY) Kuning Telur Ayam yang Diimunisasi Streptococcus mutans
}

\author{
Mufidana Azis*, Dhinintya Hyta N.*, Aurita Siwi R.*, Kristiyani Dwi M.**, Norma Dias L.*, dan Juni Handajani** \\ * Fakultas Kedokteran Hewan, Universitas Gadjah Mada Yogyakarta \\ **Bagian Biologi Mulut, Fakultas Kedokteran Gigi, Universitas Gadjah Mada \\ **JI Denta no 1 Sekip Utara Yogyakarta, email: junihandajani@yahoo.com
}

\begin{abstract}
ABSTRAK
Prevalensi karies di Indonesia menunjukkan angka yang tinggi. Karies diketahui sebagai penyakit multifaktorial rongga mulut yang disebabkan oleh bakteri Streptococcus mutans. Salah satu metode terbaru pencegahan karies gigi, yaitu, melalui imunisasi pasif menggunakan antibodi kuning telur ayam (Yolk Immunoglobulin/lgY). Beberapa penelitian menunjukkan waktu produksi IgY bervariasi dengan perbedaan teknik pengujian. Tujuan penelitian ini adalah untuk mengetahui waktu yang dibutuhkan untuk memproduksi IgY kuning telur ayam yang diimunisasi S. mutans. Metode penelitian menggunakan 4 ekor ayam Hysex Brown sebagai kelompok perlakuan dan 1 ekor ayam sebagai kontrol. Suspensi S. mutans diinjeksikan pada ayam saat minggu pertama hari ke-1,2,3, kemudian ditambahkan Freund Adjuvant pada minggu ke-2 hingga minggu ke-4. Koleksi kuning telur ayam dilakukan mulai minggu ke-2 setelah imunisasi. Untuk mengetahui efektivitas vaksinasi dan keberadaan S.mutans, kuning telur ayam selanjutnya diuji dengan AGPT (Agar Gel Precipitation Test) dan hasilnya dinyatakan positif apabila terbentuk presipitasi diantara sumuran antigen dan antibodi.. Hasil penelitian menunjukkan hasil positif pada kuning telur ayam minggu ke-5. Disimpulkan bahwa waktu yang dibutuhkan untuk produksi lgY spesifik S. mutans pada kuning telur ayam mulai minggu ke-5 setelah imunisasi.
\end{abstract}

Maj Ked Gi. Juni 2013;20(1): 31 - 34 .

Kata kunci: waktu produksi, yolk immunoglobulin (IgY), kuning telur ayam, Streptococcus mutans.

\begin{abstract}
Production Time of Yolk Immunoglobulin (Igy) Yellow Chicken Egg Immunized with Streptococcus mutans. Dental caries prevalence in Indonesia appears in high rate. Caries is known as a multifactorial disease in oral cavity caused by Streptococcus mutans bacteria. The latest method to prevent dental caries is through passive immunization using chicken yolk antibody (Yolk Immunoglobulin/lgY). Some researches showed the variation of IgY production time using different testing technique. The purpose of this research is to determine the time required to produce IgY chicken yolk immunized by S. mutans. For the method, this research uses 4 chickens of Hysex Brown as the treatment group and a chicken as the control. S. mutans suspension is injected to the chicken from $1^{\text {st }}, 2^{\text {nd }}$, and $3^{\text {rd }}$ day in the first week; Freund Adjuvant was added in the $2^{\text {nd }}$ till $4^{\text {th }}$ weeks. Collection of chicken yolk was started at $2^{\text {nd }}$ week after immunization. The chicken yolk then was tested using Agar Gel Precipitation Test (AGPT) to know the effectiveness of vaccination and the existence of S. mutans. The result of the test can be positive if it forms precipitation between antigen and antibody wells. The result has shown a positive response in chicken yolk in the $5^{\text {th }}$ week. From the test, it can be concluded that the time required for the production of IgY specific against S. mutans in chicken yolk is in the beginning of $5^{\text {th }}$ week after immunization.

Maj Ked Gi. Juni 2013;20(1): $31-34$
\end{abstract}

Keywords: time production, yolk immunoglobulin (IgY), chicken yolk, Streptococcus mutans.

\section{PENDAHULUAN}

Memasuki abad ke-21, dunia mengalami masalah pandemik yang cukup serius mengenai penyakit karies gigi terkait peningkatan jumlah penderita dari masa ke masa. Menurut Bagramian, ${ }^{1}$ di Amerika Serikat, data menunjukkan bahwa terdapat prevalensi dental karies sekitar 50\% pada anak 5 hingga 9 tahun, dan prevalensi tersebut meningkat menjadi 78\% pada usia 17 tahun ke atas. Riset Kesehatan Dasar (Riskesdas) tahun 2007 oleh Departemen Kesehatan RI menunjukkan bahwa kerusakan gigi karena karies dialami oleh $72,1 \%$ penduduk, 46,5\% merupakan karies aktif yang tidak mendapatkan perawatan. Bagramian' menyatakan permasalahan karies gigi harus mendapatkan perhatian dan dicarikan solusinya karena karies 


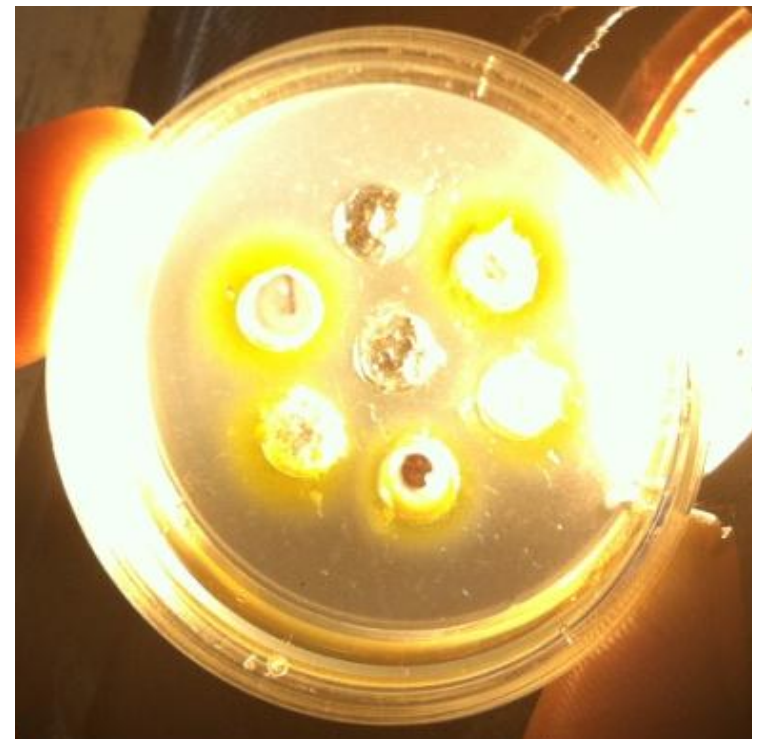

(A)

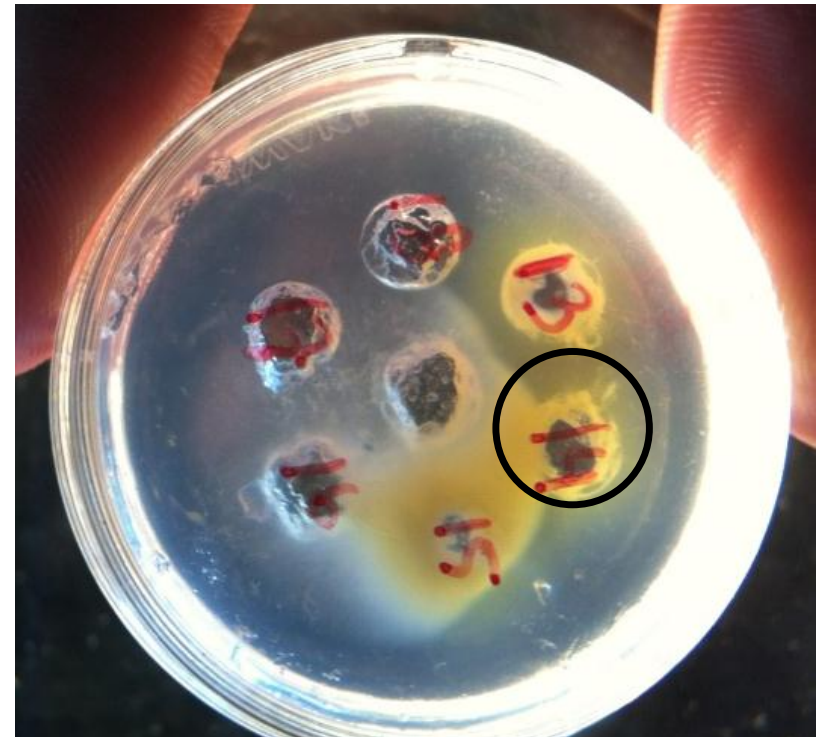

(B)

Gambar 1. Hasil uji agar gel presipitation (AGPT) menunjukkan reaksi negatif pada telur minggu ke-2 dan ke-3 (A). Hasil positif dengan adanya presipitasi (lingkaran) tampak pada telur minggu ke-5 (B).

gigi dapat berdampak negatif terhadap penyakit sistemik.

Karies diketahui sebagai penyakit multifaktorial rongga mulut. Penyakit ini diawali proses perlekatan (adhesi) bakteri Streptococcus mutans pada permukaan gigi. Pencegahan terhadap adhesi S. mutans merupakan upaya preventif yang dapat menurunkan tingginya angka karies gigi. Salah satu metode terbaru dalam melakukan tindakan preventif karies gigi adalah dengan menghambat aktivitas adhesi antigenik pathogen melalui imunisasi pasif menggunakan antibodi kuning telur ayam (lgY). Penelitian Rajan et al, ${ }^{2}$ diperoleh data bahwa antibodi kuning telur spesifik terhadap $S$. mutans, sehingga mampu mencegah terjadinya perkembangan karies gigi melalui imobilisasi dan penekanan potensi perlekatan biofilm bakteri.

\section{METODE PENELITIAN}

Produksi IgY Spesifik S. mutans dalam Telur. Produksi antibodi menggunakan 5 ekor ayam petelur (Hysex Brown-merek dagang) berumur 14-
15 minggu yang siap bertelur dalam 4 minggu ke depan. Ayam sebanyak 4 ekor diberi perlakuan, dan 1 ekor ayam sebagai kontrol. Sebanyak 4 ayam diimunisasi dengan $0,5 \mathrm{ml}\left(10^{9} \mathrm{CFU}\right)$ suspensi $S$. mutans secara intramuskular pada minggu pertama selama tiga hari, yaitu hari ke-1. 2, dan 3. ${ }^{4}$ Kemudian dilanjutkan dengan imunisasi minggu ke-2 dengan $1 \mathrm{ml}\left(10^{9} \mathrm{CFU}\right)$ suspensi bakteri S. mutans dalam Freund adjuvant complete secara intraperitoneal, serta imunisasi minggu ke-3 dan 4 dengan $1 \mathrm{ml}$ suspensi S.mutans $\left(10^{9} \mathrm{CFU}\right)$ dalam Freund Adjuvant Incomplete secara intraperitoneal. Satu minggu setelah imunisasi terakhir, dilakukan koleksi telur untuk diperiksa keberadaan antibodi telur. Untuk melakukan identifikasi keberadaan IgY spesifik $S$. mutans dalam kuning telur, digunakan Uji agar gel presipitation test (ACPT). ${ }^{3}$

\section{Ekstraksi Imunoglobulin Y (IgY) dari Kuning} Telur dengan Teknik Purifikasi Sederhana. Kuning telur dipisahkan dari putih telur, kemudian diletakkan di atas kertas saring. Satu bagian kuning telur ditampung ke dalam tabung conical centrifuge tube, kemudian ditambahkan 2 bagian PBS $\mathrm{pH} 7.5$ sampai 7.6. Campuran dalam conical centrifuge tube 
tersebut dihomogenkan dengan vortex, kemudian disentrifus dengan kecepatan 2.000 rpm selama 10 menit. Supernatan yang dihasilkan digunakan dalam Uji agar gel presipitation test (AGPT). ${ }^{3}$

Uji Agar Gel Presipitation Test. Agar gel dibuat dengan melarutkan $0,4 \mathrm{~g}$ agarose dan $1,2 \mathrm{~g}$ PEG 6.000, dalam $20 \mathrm{ml}$ PBS $0,5 \mathrm{M} \mathrm{pH} 7,4$ dan 20 $\mathrm{ml}$ aquadest $\mathrm{pH} 7,4$. Larutan ini ditangas pada air mendidih sampai larut dan warna larutan menjadi jernih. Agar cair dituang dengan pipet sebanyak $3 \mathrm{ml}$ ke dalam petridish diameter $35 \mathrm{~mm}$ dan ditunggu sampai mengeras. Lubang-lubang dibuat di atas agar dengan menggunakan alat gel puncher. Lubang tengah diisi dengan $25 \mu \mathrm{l}$ antigen S. mutans sedangkan lubang di sekitarnya diisi dengan 25 $\mu \mathrm{l}$ kuning telur yang telah dipurifikasi sederhana. Petridish diletakkan di atas kertas saring basah supaya terjaga kelembabannya. Reaksi dibaca setelah 18 48 jam, reaksi positif ditunjukkan dengan adanya garis presipitasi diantara sumur antigen dan kuning telur. $^{5}$

\section{HASIL PENELITIAN}

Hasil Uji Agar Gel Presipitation (ACPT) menunjukkan waktu produksi lgY mulai minggu ke5. Hal ini diketahui dari hasil positif yang ditunjukkan dengan adanya presipitasi (lingkaran) tampak pada telur minggu ke-5 seperti ditampilkan pada Gambar 1.

\section{PEMBAHASAN}

Produksi lgY spesifik S.mutans dilakukan dengan imunisasi pasif menggunakan suspensi S.mutans pada minggu ke-1 secara intravena, penambahan freund adjuvant complete pada minggu ke-2 secara intraperitoneal, dan freund adjuvant incomplete pada minggu ke-3 dan ke-4 secara intraperitoneal. Penambahan freund adjuvant baik complete dan incomplete bertujuan untuk memperpanjang persistensi antigen, meningkatkan sinyal costimulatory, menginduksi formasi granuloma dan merangsang proliferasi non spesifik. ${ }^{6}$ Menurut Hay dan Westwood, ${ }^{7}$ antigen lebih bersifat imunogen saat dilarutkan bersama atau dengan adjuvant. Maka, selanjutnya imunisasi pasif dalam telur ayam akan menghasilkan antibodi spesifik S.mutans, yaitu immunoglobulin $Y(\operatorname{lgY})$ anti S.mutans.

Supaya bisa dilakukan Uji Agar Gel Presipitation Test (ACPT), kuning telur ayam harus dipisahkan dari putih telurnya karena lgY merupakan suatu protein yang terdapat pada kuning telur. Kuning telur yang mengandung $\lg Y$ anti $S$. mutans harus diencerkan terlebih dahulu dengan menggunakan PBS agar presipitasi dapat terbentuk dan bereaksi dengan antigen S.mutans.

Immunoglobulin $Y(\lg Y)$ spesifik S. mutans pada telur telah diidentifikasi menggunakan Uji Agar Gel Presipitation Test (ACPT) sebagai uji kualitatif. Ayam petelur mulai berproduksi pada umur 4,5-5,0 bulan, atau sekitar 18-20 minggu, ${ }^{8}$ sehingga telur yang dikoleksi pertama merupakan telur produksi pertama pula dari ayam tersebut. Keberadaan lgY spesifik S. mutans dapat terdeteksi dengan adanya garis presipitasi diantara sumur antigen dengan sumur antibodi kuning telur. IgY spesifik $S$. mutans belum terdeteksi pada minggu pertama hingga minggu keempat setelah imunisasi terakhir. Setelah dilakukan pengulangan imunisasi (booster), satu minggu kemudian terdeteksi adanya lgY spesifik S. mutans pada kuning telur atau tepatnya pada minggu kelima setelah imunisasi terakhir. Booster ini menggunakan prinsip respon kekebalan primer dan sekunder. Pemaparan awal ke antigen A merangsang kekebalan primer, yang berakhir dengan produksi antigen tersebut. Pemaparan berikutnya (kedua) dengan antigen A menghasilkan respon yang lebih cepat dan lebih besar. ${ }^{9}$ Pada imunisasi persiapan antibodi anti S.mutans pada ayam mungkin anti S.mutans sudah terbentuk, namun belum ditransfer ke telur ayam, karena respon kekebalan primer ini berlangsung sangat cepat, maka saat telur minggu pertama sampai keempat diuji dengan ACPT maka hasilnya negatif. Booster disini digunakan untuk merangsang respon kekebalan sekunder yang berlangsung lebih cepat dan lebih besar. Maka setelah dilakukan booster, telur ayam minggu kelima positif terhadap uji ACPT, dengan tampakan garis presipitasi diantara sumur antigen dengan sumur antibodi. 


\section{KESIMPULAN}

Untuk mengidentifikasi immunoglobulin Y (IgY) spesifik $S$. mutans secara kualitatif dapat menggunakan AGPT. Pembentukan immunoglobulin Y (IgY) spesifik S. mutans pada telur ayam Hysex terjadi pada minggu kelima setelah imunisasi pasif.

\section{DAFTAR PUSTAKA}

1. Bagramian RA, Garcia-Godoy F, Volpe AR. The global increase in dental caries: a pending public health crisis. American Journal of Dentistry. 2009; 21(1): 3-8.

2. Rajan S, S Karthika, A Michael, Gandhimathi. Generation of eggyolk antibodies in chicken (igy) against streptococcus mutans and its in vitro neutralization efficacy. Archives of Aplied Science Research. 2011; 3(5): 404-12.

3. Poetri ON, Soejoedono RD. Produksi antibodi kuning telur (igy) anti streptococcus mutans sebagai anti karies gigi. Jurnal Ilmu Pertanian Indonesia. 2006; 11(3): 6-10.
4. Carlander D. Avian IgY Antibody: In vitro and in vivo [disertasi]. Stockholm : Acta Universitatis Upsaliensis; 2002.

5. Darmawi. Antigen ekskretori/sekretori stadium $\mathrm{I}_{3}$ ascaridis galli sebagai pemicu pembentukan imunoglobulin yolk (igy) pada ayam petelur [disertasi]. Bogor: Sekolah Pasca Sarjana IPB; 2007.

6. Kuby J. Immunology. Ed 3. New York: WH Freeman and Company; 1997.

7. Hay FC. Westwood OMR. Practical Immunology. Ed 4. United Kingdom: Blackwell Publishing Company. 2002.

8. Sudarmono AS. Pedoman pemeliharaan ayam ras petelur. Yogyakarta : Penerbit Kanisius; 2007.

9. Campbell, Reece, Mitchell. Biologi. Ed 5. Jakarta: Erlangga; 2004. 